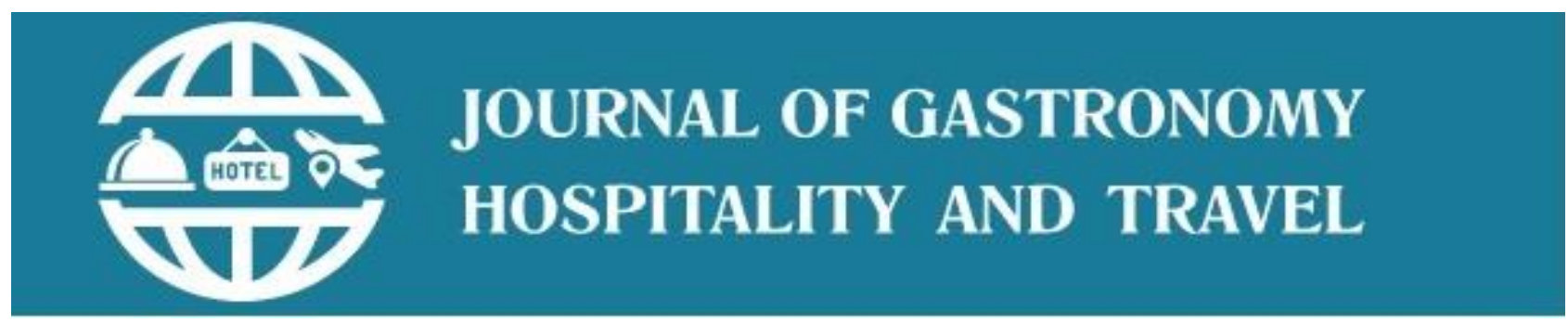

ISSN: 2619-9548

Journal homepage: www.joghat.org, http://dergipark.gov.tr/joghat

Journal of Gastronomy, Hospitality and Travel (JOGHAT)

2020 - Volume: 3 Number: 1

Page : $134-140$

Received: $12 / 05 / 2020$

Revised:08/06/2020

Accepted: $12 / 06 / 2020$

\title{
Review Article \\ EVALUATION OF HISTORICAL AND CULTURAL AREAS AS A TOOL FOR CITY MARKETING: CASE OF ESKIŞEHIR PROVINCE
}

\author{
Simge Şalvarci ${ }^{1 *}$ (orcid.org/0000-0003-0703-4126) \\ Fatmanur Kübra Aylan² (orcid.org/0000-0002-6703-2934)
}

${ }^{1}$ Tourism Management, Beysehir Ali Akkanat Tourism Faculty, Selcuk University, Konya, Turkey. ${ }^{2}$ Recreation Management, Tourism Faculty, Selcuk University, Konya, Turkey.

\begin{abstract}
In the modern world, with rapidly developing technologies and increasing competition, it is very important to apply current approaches for cities and the development of cities not only among enterprises but also regions. While trying to be at the top of the ranking of cities in the region, country or world, most cities do not always use the available resources and competitive advantages. In recent years, inadequacy of traditional techniques for urban development has emerged. City marketing is recognized as one of the modern tools to create and strengthen a city brand worldwide.

The aim of this study is to evaluate the cultural areas in Eskişehir destination as a means of city marketing. In order to construct the conceptual framework, secondary data sources compiled from Eskişehir Provincial Directorate of Culture and Tourism were used and the study was carried out with literature search. According to the findings of the study, Eskişehir has a positive cultural contribution with its rich cultural areas. At the same time, the cultural values of the region will increase the interaction of tourism actors and will contribute to the region in economic, socio-cultural and environmental terms.
\end{abstract}

Keywords: City Marketing, Cultural Sphere, Destination, Eskişehir.

\section{INTRODUCTION}

The world population has increased approximately threefold since the $1950 \mathrm{~s}$. While only $35 \%$ of the world's population lived in cities at that time, urbanization rate reached up to $85 \%$ thanks to technological developments. At the end of the 21st century; it is foreseen that $90 \%$ of human civilization will live in cities and even only $3.5 \%$ of the earth's sphere. This will lead to a new city-centered paradigm shift in all branches of science, from economy to marketing, from technology to health (Sevim, 2019).

In recent years, one of the most accepted areas of marketing is city marketing, except for the marketing of products and services. With city marketing, it is aimed to support local development and local competition by increasing the attractiveness of cities. In the marketing of the city, the product is not only tourism, agricultural products, industrial or commercial products, but all the values that the city has and wants to offer to its stakeholders (Karataş, 2017).

${ }^{1}$ To cite this document: Salvarc1, S. and Aylan, F. K. (2020). Evaluation of Historical and Cultural Areas as a Tool for City Marketing: Case of Eskişehir Province, 3(1), 134-140. DOI: 10.33083/joghat.2020.37

*Corresponding Author: simge_tokay@ hotmail.com 
City marketing is often used as a response to some economic, political and social changes in cities and their operational environments (Ashworth and Voogd, 1990). In a challenging area of competition, cities are increasingly using scarce and increasingly mobile resources in an effort to position themselves strongly.This competition strengthens the mission undertaken by the cities in the economic system and imposes important tasks on the cities in the development of countries / regions. Accordingly, cities focus on getting more shares from tourism, national / international investments, obtaining more resources, attracting more visitors and attracting more settlers. At the same time, competition is increasing day by day, and cities need to develop and implement marketing strategies such as products and services. Cities that want to increase their competitiveness, increase the number of tourists and visitors, develop their existing economic units, and expand their economies and export volumes with new investments can only reach their goals through city marketing (Sadaklığlu, 2014).

Outward elements of city marketing are culture and tourism. Not every city has the sea-sun-sand trio which is the basis of mass tourism. As a means of overcoming this disadvantage, cultural tourism which has capable of continuity in four seasons is preferred. Cities that draw attention to their historical and cultural heritage, focus on alternative tourism activities, and arrange festivals and carnivals with their local features try to stand out by using these elements (Karakullukcu, 2016).

In this study, the cultural areas of Eskişehir are evaluated in the context of city marketing. As a research area, city marketing and cultural area issues are reviewed and cultural areas in the city are discussed. In addition, the importance of these areas for city tourism is briefly evaluated.

\section{CONCEPTUAL FRAMEWORK}

City is a mixed community in which all kinds of products, including agricultural, industrial goods, trade and services, as well as agricultural products, are distributed, concentrated in a certain area, where people are divided into social classes, occupational duties are multiplied, vertical and horizontal movements are intense, including various social groups with local or universal relations, where activities of community societies are gradually increasing, with representatives of central and local governments and administrative institutions (Bal, 1999). Cities are accommodation units like villages, towns. However, these settlements differ due to various features. The most important differences are the population and economic structure. The city is a place where people live together, housing a certain population, dominating the industrial and service sectors in economic life, and having administrative organizational units (Sadaklığlu, 2014).

The concept of city marketing emerges due to the increasing importance of cities. According to Deffner and Liourius (2005) city marketing is the marketing the city as a product as in the understanding of marketing and is marketing with the image unlike the understanding of marketing.City marketing is the process of planning and designing cities to meet the needs of customers, also called city target markets (Guo and Liu, 2006; Kavaratzis, 2004; Kavaratzis and Ashworth, 2005; Kotler et al., 1999). It is also a process involving various activities. It begins with a detailed analysis of the current situation by conducting extensive research on the city's assets, opportunities and inhabitants (Kavaratzis and Ashworth, 2007). The second step is to identify and select a specific vision for the goals that can be achieved with the cooperation and agreement between the city and as many stakeholders as possible. Then comes the stage of planning specific projects that will collectively achieve the goals and allocate clear roles for the participant organizations. This is followed by the active implementation of spatial / functional, financial, organizational and promotional city marketing measures (Ashworth and Voogd, 1990). The process ends with monitoring and evaluating the results of all activities regularly (Kavaratzis, 2007).

There are three components of city marketing. These are target market, marketing factors and planning process. Target market is target audience; marketing factors are the prominent aspects of the city and the planning process means that all these should be done in a controlled manner and follow certain steps. Therefore, strategies should be identified and implemented by analyzing the city's potential and target audience (Sevim, 2019).

Although the city marketing process has an impact on culture, conservation and heritage, it also has its own unique and different images drawn from various cultural elements such as traditions, heritage and culture (Ismail and Mohd-Ali, 2011). The cultural attractiveness of cities has their own value. The cultural areas in the rapidly developing tourism sector have important contributions to the economic destination (Atsiz and 
K1z1lırmak, 2017). If the city marketing process is successfully carried out, some gains will be achieved. The most important of these gains is that the expectations of the people living in the city will be met and the satisfaction level of living in the city will increase with the studies to be carried out. Other gains are as follows (Altunbaş, 2007: 158, Gümüş, 2017);

- Attracting tourists and visitors,

- To attract investment from other cities,

- Maintain and improve the current business and investment situation,

- Growing small jobs and opening new ones

- To enable businesses to export more products abroad,

- To increase the population and to ensure homogeneous distribution within itself.

\section{METHODOLOGY}

The research was designed with quantitative research method. Secondary data was used in the research. Eskişehir province, which has rich cultural resources, was chosen as the research area of the study. Secondary data used in the study was obtained from Eskişehir Provincial Directorate of Culture and Tourism. The data in the "Eskişehir Cultural Heritage Inventory" tab of the Eskişehir Provincial Directorate of Culture and Tourism was used. In this research, present cultural areas in Eskişehir province are divided into five themes as"'Museums ", "Caravanserais and Inns" "Green Areas and Parks", "Complexes, Mosques and Tombs" and "Other Cultural Areas". In this context, the aim of the reserach is to evaluate the cultural areas in the Eskişehir destination as a city marketing tool. In this research, it is suggested that cultural areas should be used as an important tool in city marketing and recommendations are made in general.

In the research, in order to determine the cultural areas of Eskişehir destination as city marketing tool, the following research questions were analyzed:

What are the categories of cultural areas in Eskişehir?

$>$ Is there any contribution of cultural areas in Eskişehir to city marketing?

\section{FINDINGS}

As the immovable cultural assets of Eskişehir, there are 4 monuments and memorials, 498 archaeological sites, 9 military buildings, 21 archaeological and natural sites, 134 religious buildings, 150 industrial and commercial buildings, 61 administrative buildings, 4 ruins, 4 urban sites Area, 2 Conservation Areas, 84 Cultural Structures, 26 Cemeteries, 1072 Civil Architecture Examples, 2 Martyrs' Cemeteries, 1 Archeological Site. There are 2072 immovable cultural assets in Eskişehir province in total. 


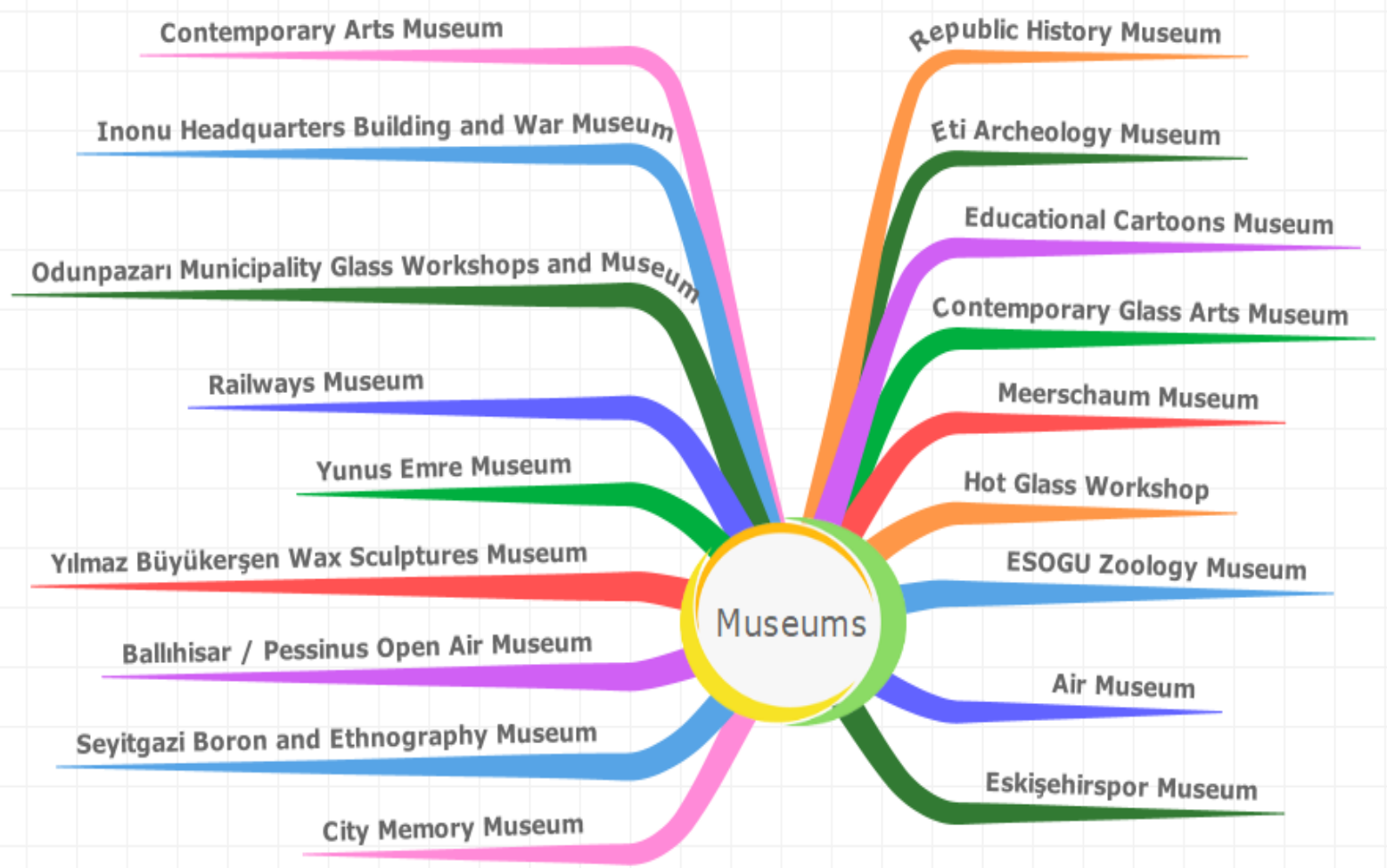

Figure 1. Museums in Eskisehir

Figure 1 shows the distribution of museums in Eskişehir. In the province of Eskisehir, it has been determined that there are 18 museums in total impending Eti Archeology Museum, Republic History Museum, Contemporary Arts Museum, Contemporary Glass Arts Museum, Meerschaum Museum, Educational Cartoons Museum, ESOGU Zoology Museum, Air Museum, Inonu Headquarters Building and War Museum, Odunpazarı Municipality Glass Workshops and Museum, Hot Glass Workshop, City Memory Museum, Railways Museum, Yunus Emre Museum, Yılmaz Büyükerşen Wax Sculptures Museum, Ballıhisar / Pessinus Open Air Museum, Seyitgazi Boron and Ethnography Museum, Eskişehirspor Museum.

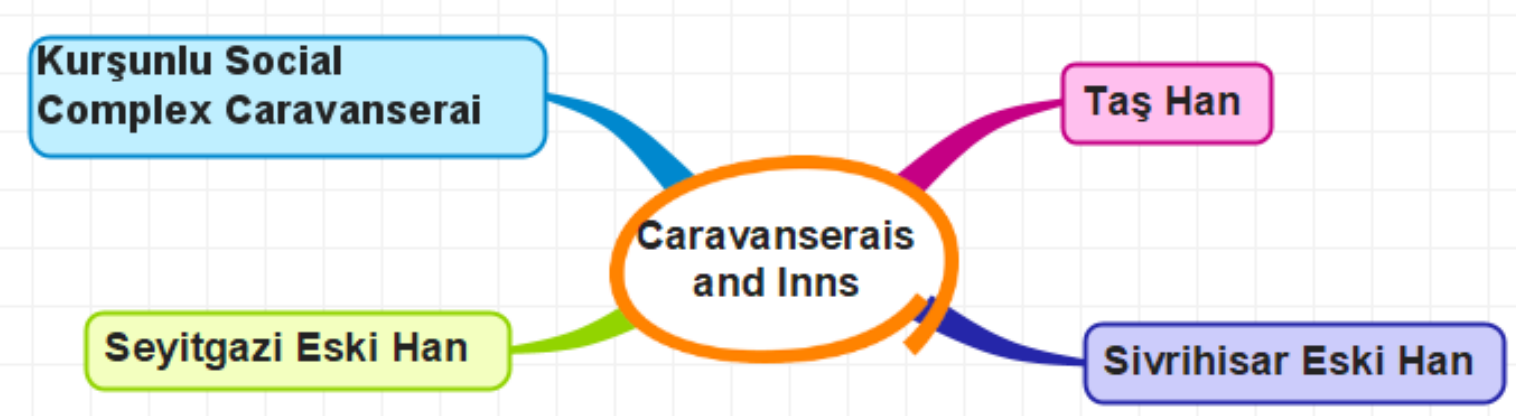

Figure 2. Caravanserais and Inns in Eskişehir

Figure 2 shows the distribution of caravanserais and inns in Eskişehir. It is seen that there are 1 Caravanserai and 2 Inns in Eskişehir. These are Kurşunlu Social Complex Caravanserai, Taş Han, Seyitgazi Eski Han and Sivrihisar Eski Han. 


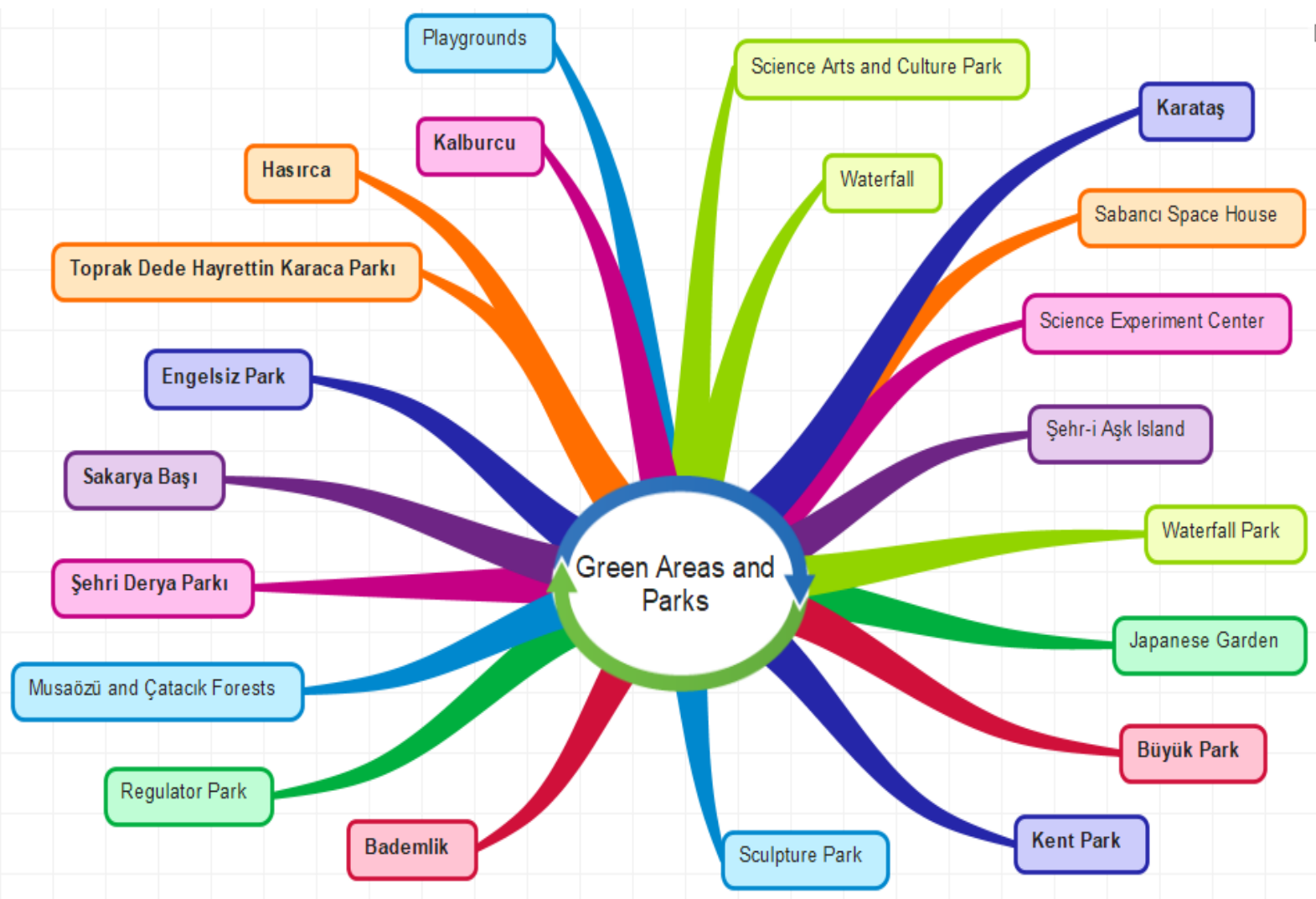

Figure 3. Green Areas and Parks in Eskişehir Province

As shown in Figure 3, Kent Park, Science Arts and Culture Park, Playgrounds, Sabanc1 Space House, Science Experiment Center, Japanese Garden, Büyük Park, Şehr-i Aşk Island, Sculpture Park, Toprak Dede Hayrettin Karaca Park, Waterfall Park, Şehri Derya Park, Engelsiz Park, Regulator Park, Bademlik, Hasırca, Kalburcu, Karataş, Sakarya Başı, Waterfall, Musaözü and Çatacık Forests, are located in Eskişehir province including a total of 21 green areas and parks.

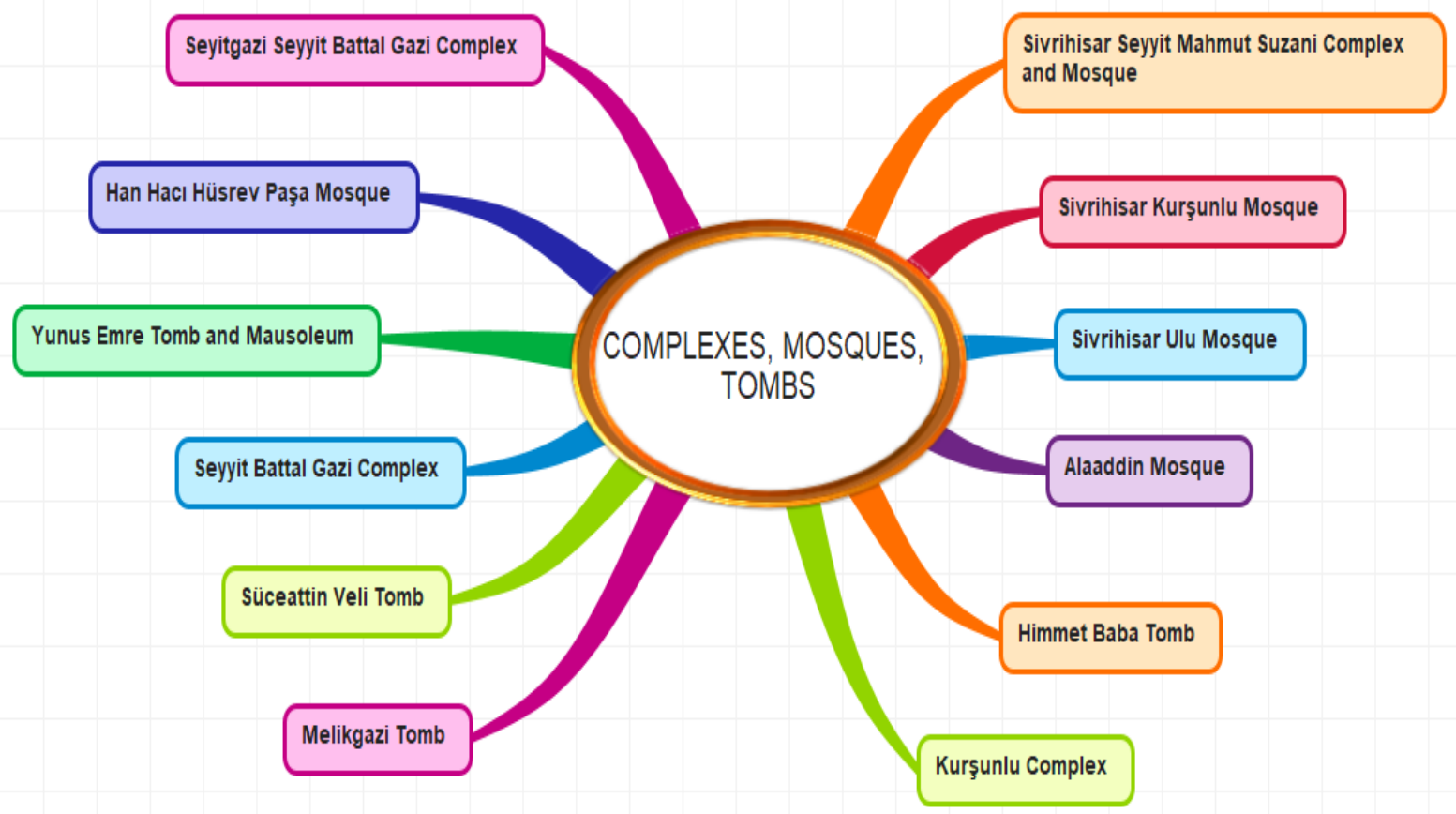


Figure 4. Complexes, Mosques and Mausoleums in Eskişehir

Figure 4 shows the distribution of Complexes, Mosques and Tombs in Eskişehir province. In the destination of Eskişehir, there are 4 complexes including Kurşunlu Complex, Seyyit Battal Gazi Complex, Seyitgazi Seyyit Battal Gazi Complex and Sivrihisar Seyyit Mahmut Suzani Complex;5 mosques including Alaaddin Mosque, Sivrihisar Grand Mosque, Sivrihisar Kurşunlu Mosque, Han Hacı Hüsrev Paşa Mosque, Sivrihisar Seyyit Mahmut Suzani Mosque and 4 tombs including Yunus Emre Tomb and Mausoleum, Süceattin Veli Tomb, Melikgazi Tomb and Himmet Baba Tomb.

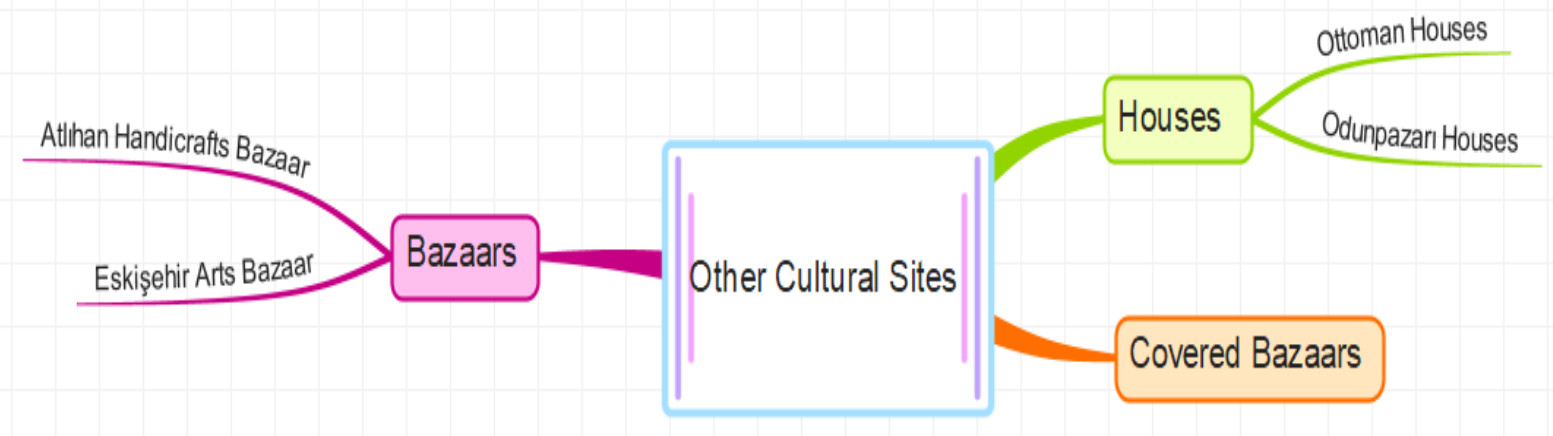

Figure 5. Other Cultural Sites in Eskişehir Province

In Figure 5, the other cultural areas in Eskişehir are considered as bazaars, houses and covered bazaars. When bazaars are evaluated as cultural areas in Eskişehir province, Atlıhan Handicrafts Bazaar and Eskişehir Arts Bazaar are located in destination. In addition, Eskişehir province has cultural areas such as Bedesten, Odunpazarı and Ottoman Houses.

\section{CONCLUSION}

City marketing is one of the key concepts that have been verified by numerous studies for the effective development of a city. It is possible to say that various marketing techniques can be successfully applied in relation to cities and local urban areas. A variety of marketing tools can be used successfully without disregarding the specificity and priority of each city. It is important to strengthen the elements that effectively maximize the position of the city. Implementing the marketing approach enables analysis of the region in terms of its main stakeholders and these stakeholders are business investors, public and government bodies, city residents. This approach also allows for a comprehensive regional assessment of the most important socioeconomic and environmental parameters.

Eskişehir province, which hosts many civilizations with its history based on Hittites and Phrygians, has brought the city closer to the level of developed European cities with its two universities, cultural infrastructure, art buildings, aviation center, planned industry, underground wealth and social life options as well as developing urbanism understanding and practices. As a result of the research, various museums such as Archeology Museum, Glass Arts Museum, Zoology Museum, Air Museum, Wax Sculptures Museum and Open Air Museum are in the category of museums in Eskişehir. In the category of caravanserai and inns, there are important cultural areas such as Kurşunlu Külliyesi Caravanserai, Taş Han, Seyitgazi Eski Han and Sivrihisar Eski Han. In the category of green areas and parks located in the city, there are parks in various themes such as Kent Park, Science Arts and Culture Park, Japanese Garden, Grand Park, Şehr-i Aşk Island, Sculpture Park, Toprak Dede Hayrettin Karaca Park, Waterfall Park, City Derya Park, Engelsiz Park, Regulator Park. Complexes, Mosques and Tombs group has been found to have many important buildings. In addition to this, other cultural areas include bazaars, houses and other wealth in the province. 
These rich cultural areas of Eskişehir have an important place in the marketing of the city. The effective use of these cultural areas as a marketing tool will increase the number of domestic and foreign potential tourists to Eskişehir. Perspectives on the use of city marketing in future research can be taken. In this research, data were obtained by using qualitative method. Subsequent research may involve diversity by using quantitative methods. In addition, the scope of the research can be expanded by evaluating the cultural areas and attractions in different provinces as a means of city marketing.

\section{REFERENCES}

Altunbaş, H. (2007). Pazarlama İletişimi ve Şehir Pazarlaması, Selçuk İletişim, 4 (4).

Ashworth, G., J. ve Voogd, H. (1990).Selling The City Belhaven Press, London.

Atsız, O., \& Kızılırmak, İ. (2017). Mardin'in Doğal ve Kültürel Çekiciliklerinin Destinasyon Pazarlaması Kapsamında İncelenmesi. Mukaddime, 8(1), 25-41.

Bal, H. (1999), Kent Sosyolojisi(1.Bask1), Turhan Kitabevi, Ankara.

Deffner A. \& Liourius C. (2005). "City Marketing: A Significant Planning Tool For Urban Development In a Globalised Economy”, 45th Congress Of the European Regional Science Association”, Vrije University Amsterdam.

Guo, G. Q., \& Liu, Y. P. (2006). The new development of the research on city marketing. Contemporary Economy\& Management, 28 (2), 5-12.

Gümüş, N. (2017). Şehir Pazarlaması Bağlamında Üniversite Öğrencilerinin Şehre Yönelik Algılarının Belirlenmesi: Kastamonu İlinde Bir Araştırma. Pamukkale Üniversitesi Sosyal Bilimler Enstitüsü Dergisi, (26), 299-314.

Ismail, S. \& Mohd-Ali, N. A. (2011). The Imaging of Heritage Conservation in Historic City of George Town for City Marketing. Procedia Engineering, 20, 339-345.

Karakullukcu, B. (2016). Eskişehir 2013 Türk Dünyası Kültür Başkentliği'nin Ulusal Basındaki Yansımalarının Şehir Pazarlaması Ekseninde Değerlendirilmesi. Yüksek Lisans Tezi. Eskişehir Osmangazi Üniversitesi Sosyal Bilimler Enstitüsü.

Karataş, İ. A. (2017). Şehir Pazarlaması Açısından Marka Şehir Göstergelerinin Belirlenmesi Üzerine Bir Araştırma: Malatya Örneği. Doktora Tezi. İnönü Üniversitesi Sosyal Bilimler Enstitüsü, Malatya.

Kavaratzis, M. (2004) From city marketing to city branding. Place Branding 1(1), 58-73.

Kavaratzis, M. \& Ashworth, G J. (2005). City branding: an effective assertion of identity or a transitory marketing trick?Tijdschrift Voor Economischeen Social eGeografie 96(5), 506-514.

Kavaratzis, M. (2007). City marketing: The past, the present and some unresolved issues. Geography compass, 1(3), 695-712.

Kavaratzis, M. \&Ashworth, G. J. (2007). Partners in coffee shops, canals and commerce: Marketing the city of Amsterdam. Cities, 24(1), 16-25.

Kotler, P, Asplund, C, Rein, I. \& Heider, D. (1999). Marketing Places Europe. Pearson Education, London.

Sadaklığlu, H. (2014). Şehir Pazarlaması Açısından Algılanan Pazar Odaklılık ile Algılanan Performans Arasındaki İlişki. Doktora Tezi. Sakarya Üniversitesi Sosyal Bilimler Enstitüsü.

Sevim, M. A. (2019). Şehir Pazarlamasında Meydanların Etkin Yönetiminin Rolü ve Önemi: İstanbul Meydanları Üzerine Bir Araştırma. Doktora Tezi. Yıldız Teknik Üniversitesi Sosyal Bilimler Enstitüsü, İstanbul. 